«Финансы, денежное обращение и кредит» / Галина Васильевна Крафт; Санкт-Петербургский государственный университет экономики и финансов. - СПб, 2006. - 40 с.

8. Лапидус Б.М. Основные направления экономических исследований на железнодорожном транспорте в условиях его кардинального реформирования / Б.М. Лапидус, И.С. Беседин, Л.А. Мазо // Вестник ВНИИЖТ. 2004. - № 3. - С. 3-13.

9. Макаренко М.В. Проблеми та основні напрямки реформування залізничного транспорту України / М.В. Макаренко, Ю.М. Цвєтов та ін. К.: КУЕТТ, 2007. - 222 c.

10. Мирошниченко О.Ф. Экономические проблемы развития железнодорожного транспорта на этапах его инновационных и структурных преобразований / О.Ф. Мирошниченко. - М.: Интекст, 2009. - 280 с.

11. Сич С.M. Інноваційно-інвестиційні комплекси транспорту : методологія формування та розвитку: [монографія] / С.М. Сич, В.П. Ільчук. - К.: Логос, 2006. - 264 с.

12. Drew J. European railway reform and performance / J. Drew // The Voice of European Railways, 25th March 2009. [Электронный ресурс] Режим доступа: http://www.indianrailways.gov.in/railwayboard/upload s/directorate/ planning/Workshop $\% 20$ \%20PLG\%20COMM,\%20IR,\%20WORLD\%20BAN
K/ 25.03.09/Jeremy.pdf. - Название с экрана.

13. Nash C. The Economic Effects of High Speed Rail Investment / C. Nash, R. Vickerman, J. Valido and E. Dávila. - Las Palmas (Spain), OECD/ITF, 2008. - 36 p.

14. Railroad economics / Ed. by S.M. Dennis, W.K. Talley // Research in transportation economics. 2007. - Vol. 20. - 292 p.

15. Хореев А.И. Формирование стратегии предприятия / А.И. Хореев, А.Н. Морозов, Е.В. Сухоруков // Экономический анализ: теория и практика. - 2008. - № 16. - С. 8-11.

16. Association agreement between the European Union and its member states, of the one part, and Ukraine, of the other part. - $906 \mathrm{p}$.

17. Равилов В. Разработка антикризисной инвестиционной программы / В. Равилов // GoodTips.PRO - Полезный интернет-журнал. . [Электронный ресурс] - Режим доступа: http://good-tips.pro/index.php/business-and-

finance/investment. - Название с экрана.

18. Бланк И.А. Инвестиционный менеджмент / И.А. Бланк. - К.: Эльга, Ника-Центр. $-2001 .-448$ c.

19. Кошкин В.И.

17- Антикризисное управление: 17-модульная программа для менеджеров «Управление развитием организации». Модуль 11. / В.И. Кошкин и др. М.: ИНФРА-М, 2000. - 512 с.

Рецензент д.э.н., профессор ГЭТУТ Богомолова Н.И. Эксперт редакционной коллегии к.э.н., доцент УкрГУЖТ Токмакова И.В.

УДК 338.465:656.07

\title{
ШЛЯХИ ПІДВИЩЕННЯ ЕКОНОМІЧНОЇ ЕФЕКТИВНОСТІ ВОСНІЗОВАНОЇ ОХОРОНИ У ЗАБЕЗПЕЧЕННІ БЕЗПЕКИ НА ЗАЛІЗНИЧНОМУ ТРАНСПОРТІ
}

\author{
Лапін П.В., здобувач (ДЕТУТ)
}

\begin{abstract}
На прикладі Служби відомчої воєнізованої охорони регіональної філії «Південно-Західна залізниия» дано уявлення про методи $і$ засоби ї̈ діяльності, наводяться основні показники економічної діяльності і безпеки підрозділів відомчої охорони за останні роки. Запропоновано групи факторів, щуо визначають досягнення стійкого фінансового положення відомчої охорони на ринку послуг безпеки на залізничному транспорті.
\end{abstract}

Ключові слова: воснізована охорона, фінансова діяльність, прибуток, збитки, конкуренція. 


\title{
ПУТИ ПОВІШЕНИЯ ЭКОНОМИЧЕСКОЙ ЭФФЕКТИВНОСТИ ВОЕНИЗИРОВАННОЙ ОХРАНЫ В ОБЕСПЕЧЕНИИ БЕЗОПАСНОСТИ НА ЖЕЛЕЗНОДОРОЖНОМ ТРАНСПОРТЕ
}

\author{
Лапин П.В., соискатель (ГЭТУТ)
}

\begin{abstract}
На примере Службы ведомственной военизированной охраны регионального филиала «ЮгоЗападная железная дорога» дано представление о методах и средствах ее деятельности, приводятся основные показатели экономической деятельности и безопасности подразделений ведомственной охраны за последние годы. Предложены группы факторов, определяющих достижения устойчивого финансового положения ведомственной охраны на рынке услуг безопасности железнодорожного транспорта.
\end{abstract}

Ключевые слова: военизированная охрана, финансовая деятельность, прибыль, убытки, конкуренция.

\section{TENDENCIES OF FORMATION ECONOMIC EFFICIENCY OF MILITARIZED GUARD IN PROVIDING SECURITY ON RAILWAY TRANSPORT}

\section{Lapin P.V., PhD student (DETUT)}

The article describes the methods and means of activity and the main indicators of economic activity on the example of Militarized guard of Southwestern railways. The standard legal and departmental acts governing the public relations, developing in operating conditions of railway transport, legal status of the state bodies dealing with issues of safety and a law and order on the railroads are investigated; the most widespread threats to interests of the state, society and the individual in this sphere of the relations which are actual also the present are allocated. A group of factors that determine the achieving sustainable financial situation for security market on railways are given in the artile.

Keywords: militarized guard, finance, profit, loss competition.

Постановка проблеми. 3 початком господарської діяльності публічного акціонерного товариства «Українська залізниця» поступово відходить в минуле попередній інститут управління галуззю - Державна адміністрація залізничного транспорту. Свій статус змінять понад 40 підприємств, які раніше були окремими юридичними особами, тепер вони стануть філіями компанії i працюватимуть у структурі новоствореного публічного акціонерного товариства. Зміни торкнуться також державного регулювання тарифів, в т.ч. на охоронні послуги, на залізничному транспорті [1].

Bce це призведе до випробувань на надійність й у воєнізованій охороні, що безпосередньо займається боротьбою із погрозами та наслідками пожеж і надзвичайних ситуацій у рухомому складі, всередині виробничих, адміністративних, господарськопобутових та інших будівель, а також здійснює супровід та охорону вантажів, адже реорганізаційні зміни відбуваються і тут [2].
Очевидно, що у нових умовах роботи необхідно забезпечити стабільне функціонування служби відомчої воєнізованої охорони, зберегти позиції підрозділів охорони у встановленій царині діяльності, не допустити зниження обсягів надаваних охоронних послуг i при цьому забезпечити ї високу надійність, зберегти внесок у подолання наслідків залізничних транспортних подій, припинення і профілактику майнових і інших видів злочинів на залізничному транспорті.

Аналіз останніх досліджень і публікацій. В сучасній фаховій літературі дослідження, присвячені економічній діяльності відомчої воєнізованої охорони висвітлюються рідко і не завжди достатньо. Перевага віддається, в основному, публікації та аналізу офіційних історичних, статистичних даних або посиланню на них $[3,4,5]$. Зокрема, в статтях про відомчу воєнізовану охорону авторами досліджується лише охоронна діяльність служби, при цьому невисвітленою залишається ії діяльність, пов'язана із забезпеченням пожежно- 
профілактичної роботи та ліквідації наслідків залізничних транспортних подій.

Слід відзначити, що питання існування $\mathrm{i}$ розвитку відомчої охорони в Україні доводиться вирішувати з урахуванням лише власного досвіду та досвіду інших пострадянських країн, оскільки аналогів подібної служби на інших залізницях світу не існує [6].

\section{Виділення}

невирішених

частин загальної проблеми. $\mathrm{y}$ теоретичному $\mathrm{i}$ прикладному аспектах потребують більш поглибленого висвітлення проблеми, пов'язані із діяльністю відомчої воєнізованої охорони в умовах ринку і зростаючої конкуренції з боку приватних охоронних організацій, зокрема, факторів, що визначають досягнення стійкого фінансового положення відомчої охорони.
Метою статті $\epsilon$ визначення ключових факторів, що визначають економічну ефективність відомчої охорони в умовах конкуренції.

Виклад основного матеріалу дослідження. Розгляд питань, пов'язаних 3 економічною ефективністю воєнізованої охорони на залізничному транспорті потребує визначення iii правого стану в цілому.

Система захисту об'єктів та рухомого складу залізниці воєнізованою охороною на залізниці являє собою сукупність сил і засобів для забезпечення необхідного рівня безпеки. Структурні компоненти воєнізованої охорони залізничного транспорту узагальнені та наведені на Рисунку 1.

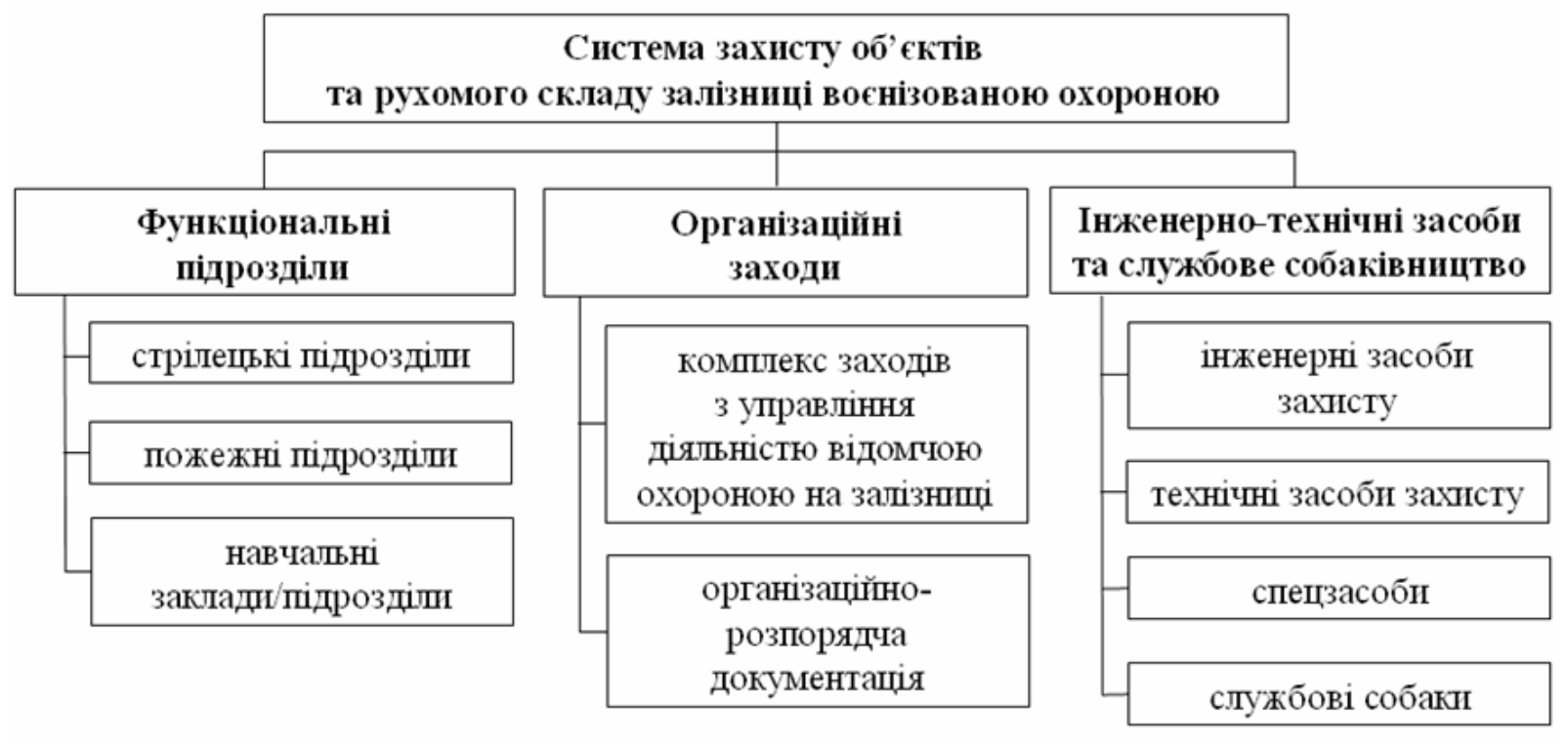

Рис.1. Узагальнена структура системи захисту об'єктів та рухомого складу залізнищі службою воєнізованої охорони

Структура i повноваження органів відомчої охорони на залізниці, норми чисельності працівників, а також порядок організації ї діяльності визначаються Положенням про відомчу воєнізовану охорону на залізничному транспорті, що затверджене постановою Кабінету Міністрів України від 11 січня 1994p. №7. Відповідно до цього Положення до відомчої охорони на залізниці належать: управління воєнізованої охорони, служби воєнізованої охорони залізниць, загони воєнізованої охорони залізниць, стрілецькі, пожежні та інші підрозділи, навчальні заклади, бази матеріального і технічного забезпечення, будинки та бази відпочинку.

Підрозділи воєнізованої охорони не $є$ юридичними особами, мають окремий баланс, поточні рахунки в банківських установах, печатки, штампи та бланки зі своїм найменуванням й інші засоби візуальної ідентифікації із зазначенням приналежності до залізниці. 


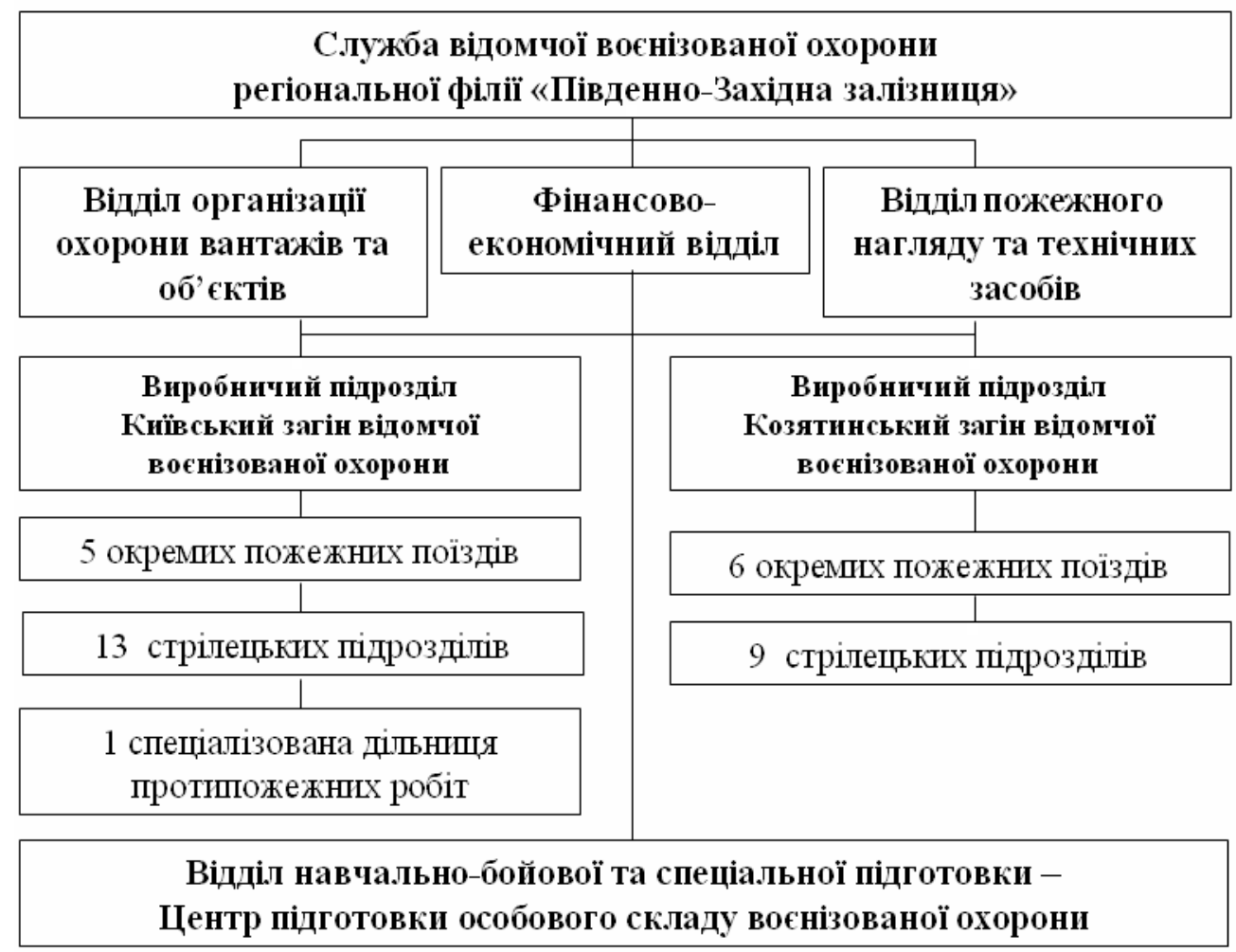

Рис. 2. Організаиійна структура відомчої воєнізованої охорони регіональної філії «Південно-Західна залізниця».

Розглянемо структуру воєнізованої охорони залізниці на прикладі служби відомчої воєнізованої охорони регіональної філії «Південно-Західна залізниця» (Рисунок 2). Служба складається 3 відділів організації охорони вантажів та об’єктів, пожежного нагляду та технічних засобів, фінансово-економічного. На сьогоднішній день до складу Служби входить 34 підрозділи, 3 них: 17 стрілецьких команд по охороні вантажів, 5 стрілецьких команд по охороні об'єктів, 1 спеціалізованої дільниці протипожежних робіт та 11 окремих пожежних поїздів.

Як видно із наведеної структури, до сфери діяльності відомчої воєнізованої охорони належить не тільки забезпечення охорони та супроводження вантажів, об'єктів, а й проведення пожежно-профілактичної роботи, ліквідація наслідків залізничних транспортних подій.

Повноваження Служби відомчої охорони в царині фінансової діяльності охоплюють наступні групи прав i обов'язків: планування власних фінансових ресурсів, розподіл $\mathrm{i}$ використання фінансових ресурсів на утримання та розвиток підрозділів, виконання фінансових зобов'язань перед державою, а також виконання зобов'язань перед господарюючими суб'єктами, здійснення фінансового контролю в службі та іiі підрозділах.

Виходячи iз вищенаведеного можна виділити головне завдання фінансовогосподарської діяльності відомчої воєнізованої охорони - досягнення стійкого фінансового положення, за якого можливе покриття витрат на iii утримання і розвиток.

Розглянемо види доходів воєнізованої охорони. Традиційно вихідними даними для аналізу даної групи показників по охоронній складовій слугують такі показники іiі діяльності: кількість пред'явлених та супроводжених поїздів, кількість припинених спроб проникнення на об'єкт, що охороняється; кількість припинених спроб порушень пропускного режиму, незбереження вантажів, які перевозяться, нестача (викрадення, нестача місць чи ваги вантажу), втрата, псування та пошкодження.

У Таблиці 1 наведено динаміку основних показників діяльності воєнізованої охорони регіональної філії «Південно-Західна залізниця» за останні роки. 
Структура фінансових надходжень воєнізованої охорони регіональної філії «Південно-Західна залізниця» за 2011-2014рр. від охоронної діяльності

\begin{tabular}{|l|c|c|c|c|}
\hline \multirow{2}{*}{ Види послуг } & \multicolumn{4}{|c|}{ Отримано коштів, тис. грн. } \\
\cline { 2 - 5 } & $2011 \mathrm{p}$. & $2012 \mathrm{p}$. & $2013 \mathrm{p}$. & $2014 \mathrm{p}$. \\
\hline Охорона вантажів & 65681,00 & 75798,00 & 81749,00 & 68341,00 \\
\hline Охорона об'єктів & 800,00 & 1408,00 & 2050,00 & 2430,00 \\
\hline Супроводження касирів & 1094,00 & 1446,00 & 1464,00 & 1337,00 \\
\hline Накладення штрафів & 43,96 & 46,07 & 38,16 & 6,43 \\
\hline Всього & 67618,96 & 78698,07 & 85301,16 & 72114,43 \\
\hline
\end{tabular}

Як видно із Таблиці 1, найбільшу частку доходу воєнізована охорона отримує від діяльності, спрямованої на охорону вантажів. Ця частка складає від 94,7\% (2014p.) до 97,1\% (2011р.). в періоді, що аналізується, а найбільш динамічний приріст доходів спостерігається від діяльності, спрямованої на охорону стаціонарних об'єктів залізничного транспорту - за період 2011-2014p. доходи від цієї діяльності потроїлися, що пов'язано як із збільшенням кількості об'єктів під охороною, так із зростанням вартості послуг відомчої охорони.

Отже, стійкий фінансовий стан воєнізованої охорони формується в результаті планомірної роботи по збільшенню отримуваних доходів, їх раціональному використанні, а також виключенням невиправданих видатків i фінансових втрат.

До основної групи фінансових втрат при здійсненні охоронної діяльності належать втрати від розкрадання майна (Таблиця 2).

Таблиия 2

Фінансові втрати воєнізованої охорони регіональної філії «Південно-Західна залізниия» за 20112014pр. від крадіжок

\begin{tabular}{|l|c|c|c|c|}
\hline \multirow{2}{*}{ Крадіжки } & \multicolumn{4}{|c|}{ Втрачено коштів, тис. грн. } \\
\cline { 2 - 5 } & $2011 \mathrm{p}$. & $2012 \mathrm{p}$. & $2013 \mathrm{p}$. & $2014 \mathrm{p}$. \\
\cline { 2 - 5 } & 1440,05 & 923,06 & 801,13 & 3385,17 \\
\hline
\end{tabular}

Співставлення фінансових показників діяльності, наведених в Таблицях 1 і 2, доводить, що воєнізована охорона достатньо ефективно дозволяє забезпечити охорону майна фізичних і юридичних осіб, що перевозиться залізницею.

Відомо, що політика ПАТ «Українська залізниця» спрямована на підвищення конкуренції та надання доступу до охорони та супроводження вантажів й приватним охоронним організаціям. Нажаль, офіційна звітність не дозволяє співставити показники діяльності, що визначають місце воєнізованої охорони на ринку охоронних послуг, наприклад, частка відомчої охорони на ринку охоронних послуг (за кількістю об'єктів, що охороняються i за обсягом отриманих доходів); рентабельність надання послуг i ii динаміка (в порівнянні 3 рентабельністю приватних охоронних організацій); рівень тарифів на послуги в порівнянні 3 вартістю охорони приватних структур; якісні параметри послуг (надійність охорони, перелік пропонованих послуг і їx комплексність).

Окрім охоронної діяльності, воєнізована охорона залізниці, виконує задачу з організації та здійснення профілактики, ліквідації пожеж i проведення пов'язаних із ними аварійнорятувальних робіт.

Не будучи безпосереднім джерелом матеріального виробництва, заходи із попередження та подолання наслідків залізничних транспортних подій відволікають значну частину грошових інвестицій, збільшуючи собівартість послуг, що надаються воєнізованою охороною. Однак, саме розміри вкладень у безпеку транспортного процесу i визначають іï рівень. Ключовими факторами, що визначають економічну ефективність заходів із 
подолання надзвичайних ситуацій на залізничному транспорті $є$ вартість у грошовому еквіваленті врятованого майна при проведенні пожежно-профілактичних робіт та вартість відверненого збитку для екології внаслідок ліквідації надзвичайної ситуації [7].

На закінчення торкнемося питань контролю за роботою відомчої воєнізованої охорони. Контроль - одна 3 функцій управління, необхідна для оцінки якості роботи. Стосовно до відомчої воєнізованої охорони на залізниці якість фінансової роботи переважно оцінюється показниками, що наведені в таблицях 1 і 2.

Висновки та пропозиції. В сучасних економічних умовах функціонування галузі виникає проблема оцінки ефективності витрат, спрямованих на забезпечення діяльності відомчої охорони, вирішення якої дозволить встановити розумні пропорції при виділенні коштів на фінансування заходів у даній царині. Не дивлячись на те, що економічна ефективність підрозділів воєнізованої охорони не є самоціллю iii функціонування, за іiі допомогою вирішується коло соціально-економічних завдань, таких як здійснення на належному рівні службових завдань, розвиток матеріально-технічної бази, соціальний захист особового складу, матеріально-фінансове забезпечення співробітників.

До основних груп факторів, що визначають досягнення стійкого фінансового положення відомчої охорони можна віднести:

1. Ефективність основної службової діяльності. Зокрема, збільшення прибутків за рахунок збільшення конкурентоздатності та, відповідно, збільшення об'ємів надаваних послуг або збільшення їх переліку. Реалізація умов зацікавленості у більших об'ємах та якості надаваних послуг та застосування тарифі на послуги, що забезпечуватимуть повну компенсацію витрат на утримання першочергове завдання служби.

2. Збільшення об'ємів надання послуг із застосуванням інженерно-технічних засобів охорони та ліквідації наслідків залізничних транспортних подій.

3. Підвищення кадрового потенціалу. Оптимізація структури i штатного розкладу в підрозділах відомчої охорони, зокрема, скорочення та здешевлення управлінського апарату. Стимулювання якості і об’єму надаваних послуг за рахунок покращення системи оплати праці та спеціального навчання.
4. Забезпечення фінансової дисципліни, зокрема, збільшення ефективності діяльності підрозділів по контролю за фінансами, збільшення ролі фінансового обліку; забезпечення жорсткого режиму економії витрат всіх видів матеріальних і грошових ресурсів. Регулярне здійснення аналізу фінансового стану i оперативне прийняття заходів по його підтримці не необхідному рівні.

5. Укріплення тилового забезпечення, в т.ч. ефективне використання службового автотранспорту, створення умов для обліку i збереження майна воєнізованої охорони.

6. Застосування показників діяльності, що визначають місце охоронної воєнізованої охорони на ринку охоронних послуг.

\section{СПИСОК ЛІТЕРАТУРИ}

1. Підлісний П. Напрямки формування корпоративного управління на залізничному транспорті в процесі його реформування / Підлісний П., Чеховська М., Паткевич Н. // Збірник наукових праць ДЕТУТ. Серія «Економіка і управління». - 2014. - Bun. 29. С 120-134.

2. Зеркалов Д.В. та ін. Пожежна профілактика на галузевих об'єктах Навчальний посібник // Зеркалов Д.В., Кацман М. Д., Кружилко О. Є., Слуговін I. І. За редакцією Д. В. Зеркалова. - К.: Основа, 2014. - 372 с.

3. Чередниченко О.Ю. Економічна доцільність відомчої системи охорони вантажів, громадського порядку на об'єктах транспортної інфраструктури України в сучасний період / Чередниченко О.Ю. // Вісник економіки транспорту і промисловості. - 2012. - №40. C.127-131.

4. Кривопішин О. Проблеми та шляхи реформування воєнізованої охорони залізничного транспорту / О. Кривошипин, Г. Ейтутіс, В. Лапін // Економіст. - 2007. - №10. - С. 30-31.

5. Запара В.М. Стан i перспективи забезпечення збереження вантажів при перевезенні залізницями України / В.М. Запара, Я.В. Запара, Н.П. Діжак // Збірник наукових праць Української державної академії залізничного транспорту. - 2014. - Вип. 146. - С. 32-37.

6. Duijnhoven H. Security Culture in the Dutch and Spanish Railway Sector. A Historical Perspective. Journal of Transport History, 2007, 28(2), pp. 272-288. 
7. Лапін П.В. Економічна ефективність транспорту. Сер.: Економіка і управління. - 2015. пожежних поїздів: до постановки проблеми / - Вип. 31. - С. 78-90. П.В. Лапін // Збірник наукових праць Державного економіко-технологічного університету

Рецензент д.е.н., професор ДЕТУТ Ейтутіс Г.Д. Експерт редакційної колегії к.е.н., доцент УкрДУЗТ Токмакова І.В.

УДК 338.2:629.4

\title{
ФОРМУВАННЯ ПАТ «УКРАЇНСЬКА ЗАЛІЗНИЦЯ»: АНАЛІЗ МАЙНОВОГО ТА ФІНАНСОВОГО СТАНУ
}

\author{
Пилипенко О. В., к.е.н., доцент, професор, \\ Соколова Е. О., к.е.н., доцент, доцент (ДЕТУТ)
}

У статті проведено аналіз майнового та фінансового стану ПАТ «Украйнська залізниия» та виділено основні особливості його оцінки, щуо обумовлені специирікою виробничо-господарської $i$ фінансової діяльності «Укрзалізниці». Встановлено, щцо особливості оцінки вартості активів, технічного стану основних фондів та інтерпретації результатів аналізу фінансових коефіцієнтів впливають на коректність оцінки фінансово-економічного стану «Укрзалізниці» $і$ прогнозованість ефективності ї̈ функціонування у майбутньому.

Ключові слова: корпоратизація залізничного транспорту, оцінка майна, вартість основних засобів, ступінь зносу, фінансовий стан, платоспроможність.

\section{ФОРМИРОВАНИЕ ПАО «УКРЗАЛИЗНЫЦЯ»: АНАЛИЗ ИМУЩЕСТВЕННОГО И ФИНАНСОВОГО СОСТОЯНИЯ}

\author{
Пилипенко Е. В., к.э.н., доцент, \\ Соколова Э. А., к.э.н., доцент (ГЭТУТ)
}

В статье проведён анализ имущественного и финансового состояния ПАО «Украинская зализныця» и выделены особенности его оченки, обусловленные спецификой производственнохозяйственной и финансовой деятельности «Укрзализныци». Определено, что особенности оценки стоимости активов, технического состояния основных фондов и интерпретации результатов анализа финансовых коэффициентов влияют на корректность оценки финансово-экономического состояния «Укрзализныци» и прогнозируемость эффективности её функиионирования в будущем.

Ключевые слова: корпоратизация железнодорожного транспорта, оценка имущества, стоимость основных средств, степень износа, финансовое состояние, платёэсеспособность.

\section{THE FORMATION OF PJSC "UKRAINIAN RAILWAY": ANALYSIS OF PROPERTY AND FINANCIAL STATE}

\author{
Pylypenko O.V., PhD, associated professor,
}

Sokolova E.O., PhD, associated professor

(State Economic and Technological University of Transport)

Implementation of the reform and corporatization of railway transport of Ukraine caused the valuation of property (including non-current assets) of Railways and their structural divisions, whose 